\title{
Pola pengelolaan pendapatan keluarga buruh tani dalam rangka memenuhi kebutuhan hidup
}

\author{
Feni Dwi Yulianti, Sri Umi Mintarti*, Wahjoedi, Yohanes Hadi Soesilo \\ Universitas Negeri Malang, Jl. Semarang No. 5 Malang, Jawa Timur, Indonesia \\ *Penulis korespondensi, Surel: sri.umi.fe@um.ac.id
}

Paper received: 25-8-2021; revised: 8-9-2021; accepted: 15-9-2021

\begin{abstract}
Income management can be identified the pattern through income and expenditure streams. This study aims to determine the pattern of income management of farm labor families in Bakung Pringgodani Village in order to meet the needs of life. This research is a qualitative research with a case study method where researchers collect data will focus on a case encountered in a family of farm workers in Bakung Pringgodani Village. The obtained data were observed and analyzed carefully to the end with the aim of understanding a phenomenon or event experienced by the family farm laborers in the village of Bakung Pringgodani. The suggestions from this study are: Farm workers' families are expected to be able to make or arrange a written financial plan so that it can facilitate the allocation of income and control expenses in order to fulfill the needs of family life.
\end{abstract}

Keywords: income management; living needs; financial planning

\begin{abstract}
Abstrak
Pengelolaan pendapatan dapat diketahui dari pola pendapatan dan pengeluaran. Penelitian ini bertujuan untuk menganalisa pola pengelolaan pendapatan pada keluarga petani untuk memenuhi kebutuhan mereka, di Desa Bakung Pringgodani. Penelitian ini merupakan penelitian kualitatif yang menggunakan metode studi kasus, dimana peneliti focus pada kasus-kasus yang dialami para keluarga petani di Desa Bakung Pringgodani. Data yang telah terkumpul diobservasi dan dianalisa untuk menjabarkan dan memahami fenomena yang dialami oleh para keluarga petani di Desa Bakung Pringgodani. Oleh karena itu, para keluarga petani disarankan untuk menyusun rencana keuangan tertulis untuk membantu pengalokasian pendapatan dan mengontrol pengeluaran dalam pemenuhan kebutuhan keluarga
\end{abstract}

Kata kunci: pengelolaan pendapatan; kebutuhan hidup; rencana keuangan

\section{Pendahuluan}

Indonesia merupakan negara agraris dimana sebagian besar wilayahnya dimanfaatkan sebagai lahan pertanian. Didukung dengan letak geografis dan iklim yang dimiliki oleh Indonesia, sehingga lahan yang ada sangat cocok untuk ditanami berbagai komoditas pertanian. Keadaan iklim di Indonesia menjadikan wilayah daratan di Indonesia sangat cocok untuk ditanami padi. Sebagian besar warga Indonesia yang tinggal di daerah pedesaan pun hidupnya sangat bergantung dengan sektor pertanian. Namun saat ini, banyak petani yang tidak memiliki lahan sendiri sehingga mereka pergi kesawah hanya sebagai pekerja atau buruh tani (BPS, 2013:43).

Buruh diartikan sebagai seseorang yang memiliki pekerjaan dalam bidang pertanian. Tetapi tidak turut menanggung resiko terhadap hasil panen. Buruh hanya bekerja memberikan jasa pada saat proses produksi mulai dari awal hingga masa panen dengan tujuan mendapatkan imbalan (Raharjo, 2007:146). Buruh tani dalam prosesnya hanya menjual jasa yang dimiliki kepada pemilik lahan persawahan untuk menggarap sawah dari mulai 
penanaman bibit padi, perawatan padi, hingga pada masa panen tiba. Terkait sistem pengupahan, menurut Herlina Wati dan Charina Chazali ada tiga jenis sistem pengupahan petani, yaitu : Sistem Upah Harian dimana jumlah upah yang diterima oleh buruh tani akan disesuaikan dengan lama waktu bekerja dan banyaknya hari kerja, Sistem Upah Borongan dimana jumlah upah yang diterima akan tergantung dengan jumlah buruh yang bekerja dalam satu bidang sawah, dan Sistem bagi hasil dimana jumlah yang diterima bergantung pada kesepakatan pembagian dengan pemilik lahan dari hasil produksi.

Badan Pusat Statistik (BPS) menyatakan upah nominal buruh tani pada Oktober 2019 mengalami kenaikan 0,12\% menjadi Rp. 38.278 perhari. Apabila seorang buruh tani memperoleh upah sebesar Rp. 38.278 per hari dan harus menghidupi seluruh anggota keluarganya, maka niscaya mereka akan berada di bawah garis kemiskinan. Apabila buruh tani bekerja selama 30 hari dalam satu bulan maka mereka akan menerima upah sejumlah Rp. 1.148.340 dalam satu bulan. Dengan kondisi buruh tani yang sudah berumah tangga, maka pendapatan yang diproleh buruh tani akan tergolong kecil apabila dihadapkan dengan seluruh kebutuhan.

Kehidupan buruh tani dinilai sulit, melihat mereka yang tidak menghasilkan banyak uang dari kerja keras yang telah mereka lakukan. Pendapatan yang diperoleh dari hasil aktivitas pertanian tidak seberapa, belum lagi adanya kemungkinan gagal panen yang bisa saja terjadi. Oleh karena itu, banyak buruh tani yang memiliki pendapatan lain dari pekerjaan sampingan lainnya untuk mencukupi kebutuhan hidup. Kebutuhan hidup yang bermacammacam seperti kebutuhan akan makanan, pakaian, tempat tinggal, dan kesehatan harus dipenuhi untuk keberlangsungan hidup. Akibat dari kebutuhan hidup yang tidak terbatas dan harus terpenuhi untuk menunjang kehidupan, mereka harus terus bekerja dengan keras dalam mencari nafkah untuk memenuhi kebutuhan hidup bagi keluarganya. Tuntutan untuk terus berjuang dalam memenuhi kebutuhan tersebut tak lain merupakan kegiatan pemenuhan kebutuhan untuk keberlangsungan hidup.

Pendapatan rendah yang diperoleh buruh tani sebenarnya bukan menjadi satu-satunya masalah yang menimbulkan kesulitan yang dihadapi. Kemampuan dalam pengelolaan keuangan pun dianggap hal yang sangat penting. Kemampuan dalam pengelolaan keuangan dapat diterapkan dalam kehidupan sehari-hari untuk menghadapi keadaan sulit yang dapat terjadi sewaktu-waktu dan juga sangat dibutuhkan untuk mempersiapkan kehidupan di masa mendatang. Untuk itu, dalam memenuhi segala kebutuhan hidup diperlukan sebuah pengelolaan keuangan yang terencana dan matang.

Pengelolaan keuangan merupakan suatu proses perencanaan, pengorganisasian, dan pengontrolan sumberdaya sebagai upaya untuk mengalokasikan pendapatan dan mengatur pengeluaran sebuah keluarga secara baik dan benar untuk mewujudkan tujuan-tujuan keuangan secara efektif dan efisien sehingga dapat memenuhi kebutuhan hidup keluarga di masa sekarang dan di masa yang akan datang. Dengan melakukan pengelolaan keuangan, keluarga dapat mengetahui berapa nilai uang yang diperoleh dari hasil kerja dan berapa nilai pengeluaran yang digunakan dalam pemenuhan kebutuhan. Dengan begitu, suatu keluarga bisa memaksimalkan pendapatan dan mengatur pengeluaran sehingga semua kebutuhan dapat terpenuhi.

Desa Bakung Pringgodani terletak di wilayah barat Kabupaten Sidoarjo yang merupakan salah satu daerah yang sebagian besar masyarakatnya bermata pencaharian sebagai petani. 
Sebagian besar dari petani di desa Bakung Pringgodani tidak memiliki lahan persawahan dan hanya bekerja sebagai buruh tani yang mengurus sawah dari proses penanaman hingga panen yang kemudian mendapatkan imbalan dengan sistem bagi hasil yang sesuai dengan kesepakatan awal dengan pemilik lahan persawahan. Pendapatan yang diperoleh dari hasil bertani yang tergolong kecil membuat buruh tani di Desa Bakung Pringgodani memiliki pekerjaan sampingan diluar sebagai buruh tani dalam rangka untuk memenuhi kebutuhan hidup mereka. Pendapatan rendah dan tidak pasti yang diperoleh keluarga petani secara tidak langsung akan menimbulkan masalah keuangan dalam keluarganya. Untuk itu, buruh tani di Desa Bakung Pringgodani melakukan pengelolaan pada pendapatan yang mereka peroleh baik dari pekerjaan sebagai buruh tani maupun dari pekerjaan sampingan mereka guna untuk memenuhi kebutuhan mereka beserta keluarga.

Berdasarkan latar belakang diatas, maka peneliti tertarik untuk melakukan penelitian dengan judul "Pola Pengelolaan Pendapatan Keluarga Buruh Tani Dalam Rangka Memenuhi Kebutuhan Hidup" yang dilaksanakan di Desa Bakung Pringgodani Kecamatan Balongbendo Kabupaten Sidoarjo.

\section{Metode}

Rancangan penelitian ini adalah rancangan penelitian kualitatif. Metode penelitian yang digunakan adalah metode studi kasus dimana peneliti mengumpulkan data akan terfokus pada suatu kasus yang ditemui dalam keluarga buruh tani di Desa Bakung Pringgodani yang kemudian dilakukan pengamatan dan analisis dengan cermat hingga tuntas.

Subjek penelitian dalam penelitian ini adalah keluarga buruh tani di Desa Bakung Pringgodani Kecamatan Balongbendo Kabupaten Sidoarjo yang tidak memiliki lahan sendiri. Jumlah informan yang dipilih dalam penelitian ini dari keluarga buruh tani terdapat 8 keluarga dengan 16 informan yang terdiri dari sepasang suami istri dalam keluarga buruh tani.

Pengumpulan data dengan menggunakan tiga teknik yaitu wawancara mendalam, observasi,dan dokumentasi. Sedangkan teknik analisis yang digunakan adalah dengan reduksi data, penyajian data, penarikan kesimpulan dan verifikasi. Untuk pengecekan keabsahan data dengan menggunakan teknik triangulasi sumber.

\section{Hasil dan Pembahasan}

Dari hasil penelitian yang dilakukan maka diperoleh hasil sebagai berikut:

Jumlah pendapatan yang diperoleh Buruh Tani dalam satu musim panen padi di Desa Bakung Pringgodani Kecamatan Balongbendo Kabupaten Sidoarjo dapat dikategorikan dalam golongan rendah. Pendapatan yang diperoleh dikategorikan rendah dikarenakan beberapa penyebab diantaranya yaitu periode musim panen yang hanya terjadi dua kali dalam satu tahun, sistem bagi hasil, dan jumlah masing-masing bidang yang digarap oleh buruh tani.

Berikut tabel pendapatan keluarga buruh tani dari hasil panen padi selama satu musim di Desa Bakung Pringgodani Kecamatan Balongbendo Kabupaten Sidoarjo: 
Tabel 1. Pendapatan Hasil Tani Keluarga Buruh Tani

\begin{tabular}{clll}
\hline No. & \multicolumn{1}{c}{ Nama } & $\begin{array}{c}\text { Pendapatan } \\
\text { Tertinggi }\end{array}$ & $\begin{array}{c}\text { Pendapatan } \\
\text { Terendah }\end{array}$ \\
\hline 1. & Sutono & Rp. 5.280 .000 & Rp. 1.600 .000 \\
2. & Sarpan & Rp. 2.600 .000 & Rp. 800.000 \\
3. & Sampun Handoyo & Rp. 2.640 .000 & Rp. 800.000 \\
4. & Ngatemo & Rp. 8.000 .000 & Rp. 2.400 .000 \\
5. & Kusno Aji & Rp. 4.800 .000 & Rp. 800.000 \\
6. & Sukir Hadi Prayitno & Rp. 5.200 .000 & Rp. 1.600 .000 \\
7. & Samingan & Rp. 2.600 .000 & Rp. 800.000 \\
8. & Suyadi & Rp. 2.640 .000 & Rp. 800.000 \\
\hline
\end{tabular}

Sumber: Hasil wawancara buruh tani Desa Bakung Pringgodani

Dari tabel diatas dapat diketahui jika pendapatan yang diperoleh buruh tani di Desa Bakung Pringgodani jauh dibawah UMK Sidoarjo sehingga dapat disimpulkan jika pendapatan keluarga buruh tani di Desa Bakung Pringgodani Kecamatan Balongbendo Kabupaten Sidoarjo tergolong rendah.

Buruh Tani memperoleh pendapatan dari hasil panen hanya di musim panen saja, dimana musim panen padi hanya terjadi dua kali dalam satu tahun. Sebagian besar Buruh Tani di Desa Bakung Pringgodani Kecamatan Balongbendo Kabupaten Sidoarjo memiliki pendapatan lain yang diperoleh diluar dari bertani, hal ini dilakukan untuk menutupi kebutuhan yang belum terpenuhi.

Pekerjaan para informan selain menjadi Buruh Tani di musim padi sangat beragam, seperti bekerja serabutan, pekerja lepas, kuli bangunanatau membuka usaha sendiri seperti berjualan dan membuka warung kopi. Pendapatan yang diperoleh para informan selain menjadi Buruh Tani diterima secara harian berkisar antara Rp. 40.000 - 100.000 perharinya.

Berikut tabel pendapatan dari pekerjaan sampingan keluarga buruh tani di Desa Bakung Pringgodani Kecamatan Balongbendo Kabupaten Sidoarjo:

Tabel 2. Pendapatan Sampingan Keluarga Buruh Tani

\begin{tabular}{llll}
\hline No. & \multicolumn{1}{c}{ Nama } & Pekerjaan Sampingan & Pendapatan/hari \\
\hline 1. & Sutono & Pekerja serabutan & Rp. 100.000 \\
2. & Sarpan & Pegawai tidak tetap & Rp. 80.000 \\
3. & Sampun Handoyo & Berdagang & Rp. 100.000 \\
4. & Ngatemo & Pekerja serabutan & Rp. 60.000 \\
5. & Kusno Aji & Berdagang & Rp. 40.000 \\
6. & Sukir Hadi Prayitno & Pekerja Borongan & Rp. 60.000 \\
7. & Samingan & Berdagang & Rp. 50.000 \\
8. & Suyadi & Kuli Bangunan & Rp. 80.000 \\
\hline
\end{tabular}

Sumber: Hasil wawancara buruh tani Desa Bakung Pringgodani

Dilihat dari tabel diatas menunjukkan bahwa pendapatan yang diperoleh buruh tani di Desa Bakung Pringgodani dari pekerjaan sampingan rata-rata dibawa Upah Minimum Kabupaten (UMK) yaitu dalam satu bulan dengan 26 hari efektif bekerja pendapatan berkisar antara Rp. 1.040 .000 - 2.600.000 sedangkan upah minimum Kabupaten Sidoarjo sebesar Rp. 4.293.000. Jumlah pendapatan dari pekerjaan sampingan tersebut tergolong dalam kategori rendah karena masih dibawah rata-rata UMK Kabupaten Sidoarjo. 
Pendapatan keluarga buruh tani dari kegiatan bertani maupun pekerjaan sampingan berkisar antara Rp. 1.935.000 - 3.880.000 sedangkan upah minimum Kabupaten Sidoarjo sebesar Rp. 4.293.000. Jadi jumlah pendapatan keluarga buruh tani tiap bulannya tersebut masih tergolong dalam kategori rendah karena masih dibawah rata-rata UMK Kabupaten Sidoarjo.

Berdasarkan hasil penelitian yang telah dilakukan diketahui bahwasanya keluarga buruh tani di Desa Bakung Pringgodani dalam pengelolaan pendapatan keluarga, ditemukan terdapat 3 macam pola yang diterapkan keluarga buruh tani di Desa Bakung Pringgodani dalam mengelola pendapatan, yaitu:

Pola 1: Pendapatan dari hasil panen dan pendapatan dari pekerjaan sampingan digabungkan dan dialokasikan untuk membiayai seluruh kebutuhan baik yang bersifat primer, sekunder dan tersier.

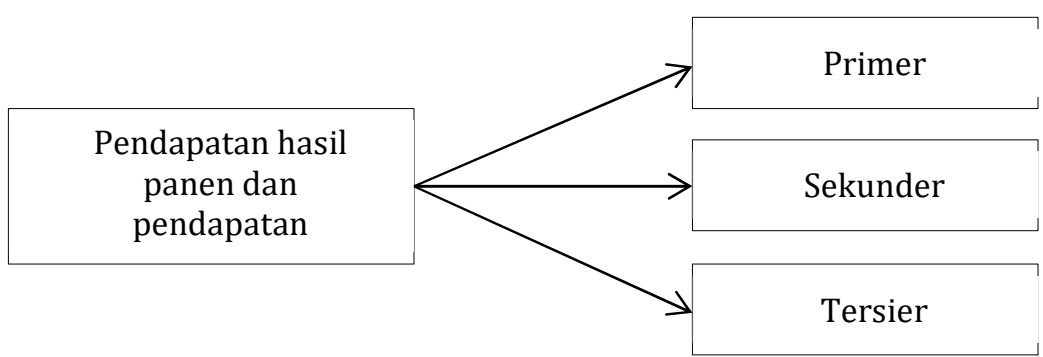

Gambar 1. Pola 1 Aliran Pendapatan dan Pengeluaran

Pola 2: Pendapatan diluar musim panen yang dialokasikan untuk membiayai kebutuhan primer, sedangkan pendapatan dari hasil panen dialokasikan untuk membiayai kebutuhan yang bersifat sekunder dan tersier.

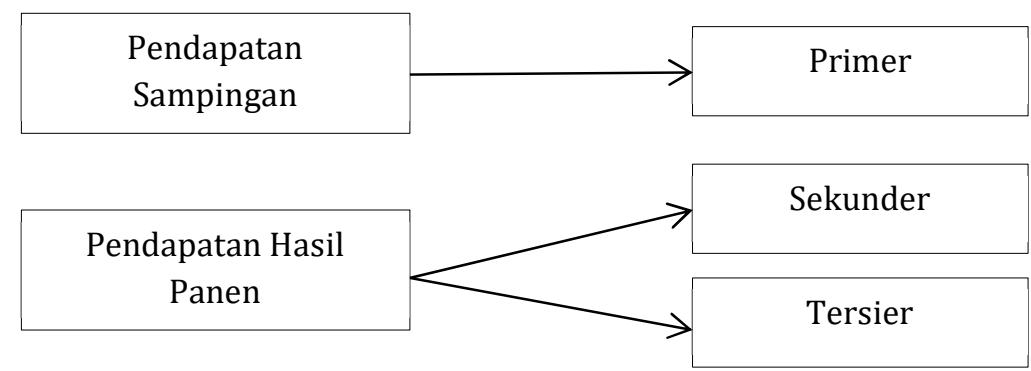

Gambar 2. Pola 2 Aliran Pendapatan dan Pengeluaran

Pola 3: Pendapatan di musim panen dialokasikan untuk membiayai kebutuhan yang bersifat primer, sedangkan pendapatan diluar musim panen dialokasikan untuk membiayai kebutuhan yang bersifat sekunder dan tersier. 


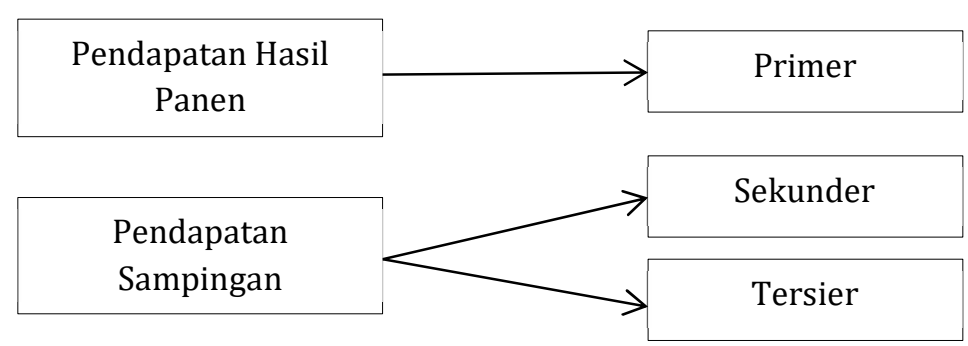

Gambar 3. Pola 3 Aliran Pendapatan dan Pengeluaran

\subsection{Pendapatan Keluarga Buruh Tani}

Keluarga buruh tani di Desa Bakung Pringgodani memiliki kedua tipe pendapatan, yaitu pendapatan dari aktivitas bertani dan pendapatan dari pekerjaan sampingan mereka. Memiliki pekerjaan sampingan di samping pekerjaan utama mereka sebagai buruh tani ini karena dorongan faktor kebutuhan yang masih belum dapat terpenuhi apabila hanya mengandalkan pendapatan dari aktivitas pertanian yang tergolong bernilai sedikit apabila disandingkan dengan seluruh kebutuhan keluarga yang harus dipenuhi. Oleh karena itu, sebagian besar buruh tani di Desa Bakung Pringgodani memiliki pekerjaan sampingan di samping menjadi buruh tani di sawah.

Jumlah pendapatan yang diperoleh Buruh Tani dalam satu musim panen padi di Desa Bakung Pringgodani Kecamatan Balongbendo Kabupaten Sidoarjo dapat dikategorikan dalam golongan rendah. Pendapatan yang diperoleh dikategorikan rendah dikarenakan beberapa penyebab diantaranya yaitu periode musim panen yang hanya terjadi dua kali dalam satu tahun, sistem bagi hasil, dan jumlah masing-masing bidang yang digarap oleh buruh tani.

Keluarga buruh tani di Desa Bakung Pringgodani menerima hasil yang tidak seberapa daripada aktivitas bertaninya. Hal ini dipengaruhi oleh beberapa faktor yang menjadi penyebab jumlah perolehan pendapatan yang diperoleh buruh tani di Desa Bakung Pringgodani dari hasil pertanian mereka bernilai sedikit, yaitu sebagai berikut:

Periode Musim Panen, buruh tani di Desa Bakung Pringgodani akan bekerja di sawah pada saat musim tanam padi di mulai. Mereka melakukan pembibitan, penanaman, perawatan tanaman padi, hingga proses pemanenan dengan waktu yang tidak sebentar. Sehingga dalam kurun waktu satu tahun, petani di Desa Bakung Pringgodani hanya dapat memanen padi sebanyak dua kali. Dapat diketahui apabila fase penanaman padi hingga panen membutuhkan waktu tunggu yang cukup lama. Tanaman padi bisa dilakukan pemanenan apabila sudah berusia sekitar 4 bulan dengan waktu tunggu 2 bulan tiap berganti musim. Sehingga periode tanam dan panen padi dalam satu tahun hanya terjadi dua kali hal ini sejalan dengan temuan Eva Gusmina, Try Susanti dan Arif Ma'rufi (2018) menyatakan bahwasanya di Kecamatan Danau pola tanam padi bisa dilakukan dua kali yaitu di awal tahun (Februari) dan akhir tahun (November) sedangkan periode panen terjadi dua kali yaitu di awal tahun (Februari) dan pertengahan tahun (Juni). Begitu pula di Desa Bakung Pringgodani, periode panen hanya terjadi dua kali setiap tahunnya.

Dengan begitu keluarga buruh tani di Desa Bakung Pringgodani hanya memperoleh pendapatannya selama satu tahun hanya sebanyak dua kali yaitu saat periode musim panen berlangsung. Pendapatan yang hanya diperoleh dua kali dalam satu tahun oleh buruh tani di Desa Bakung Pringgodani tergolong sangat kurang apabila digunakan untuk mencukupi 
seluruh kebutuhan keluarga setiap harinya. Dimana mereka hanya menerima pendapatan saat musim panen tiba tetapi kebutuhan keluarga yang setiap hari harus dipenuhi untuk terus bertahan hidup.

Sistem Bagi Hasil, buruh tani di Desa Bakung Pringgodani tidak memiliki lahan persawahan mereka sendiri, melainkan menggarap lahan persawahan milik orang lain. Dimana sebelumnya terdapat kesepakatan antara buruh tani penggarap dan pemilik lahan mengenai sistem bagi hasil. Dalam prosesnya, seluruh biaya produksi dan aktivitas penanaman bibit hingga panen menjadi tanggung jawab buruh tani sepenuhnya, pemilik lahan hanya menyediakan lahan untuk ditanami padi. Ketika periode panen tiba, hasil gerabah yang diperoleh akan dibagi antara pemilik lahan dan juga buruh tani sebagai penggarap sesuai kesepakatan diawal hal ini sesuai dengan pernyataan Dwi Wahyuni (2016) yang menyatakan bahwa dalam sistem bagi hasil pengupahan kerja dalam aktivitas pertanian diawali dengan perjanjian atau kesepakatan oleh pemilik lahan dengan penggarap sawah, dimana penggarap sawah akan melakukan suatu usaha tertentu dalam proses pertanian tanpa dibayar secara langsung, tetapi penggarap sawah memiliki hak untuk memanen hasil pertanian padi dan mengambil sebagian hasil panen yang diperoleh sesuai dengan kesepakatan di awal.

Dengan seluruh biaya produksi yang dikeluarkan selama proses penanaman hingga panen oleh buruh tani di Desa Bakung Pringgodani menjadikan buruh tani menanggung risiko yang besar apabila terjadi kegagalan panen atau puso. Karena ketika terjadi puso maka buruh tani terancam tidak mendapatkan apa-apa selain hasil panen yang sedikit hal ini sejalan dengan pernyataan Dwi Wahyuni (2016) bahwasannya ketika terjadi kegagalan panen buruh tani adalah orang yang paling dirugikan dikarenakan terancam tidak memperoleh hasil panen dan juga tidak menerima upah berupa uang tunai karena bekerja dengan sistem bagi hasil. Selain itu, dengan adanya sistem bagi hasil, jika terjadi kegagalan panen atau puso apabila hasil panen yang diperoleh sedikit, maka akan menjadi semakin sedikit karena masih harus dibagi dengan pemilik lahan sesuai dengan kesepakatan di awal.

Jumlah Bidang Garapan, beberapa buruh tani di Desa Bakung Pringgodani menggarap lebih dari satu bidang sawah milik orang agar memperoleh hasil panen yang melimpah saat periode panen tiba. Karena pendapatan yang diperoleh buruh tani di Desa Bakung Pringgodani dalam satu periode musim panen dipengaruhi oleh berapa bidang sawah yang tengah digarap. Semakin banyak bidang sawah yang digarap selama satu musim panen maka semakin tinggi pendapatan yang diperoleh karena lahan sawah yang dipanen semakin luas sehingga memperoleh hasil panen dengan jumlah yang lebih banyak dan sebaliknya semakin sedikit bidang sawah yang digarap maka akan semakin rendah pendapatan yang diperoleh karena lahan sawah yang dipanen sedikit sehingga memperoleh hasil panen dengan jumlah yang lebih sedikit, hal ini sejalan dengan hasil penelitian yang dilakukan oleh Sri Endah Nurzanah, Moral Abadi Girsang, dan Khadijah El Ramija (2020) menyatakan bahwa luas panen berkorelasi positif terhadap hasil produksi sawah di Kabupaten Serga. Juga sejalan dengan Sari dan Minahju (2016) yang menyatakan bahwa luas panen menyumbang andil besar untuk produksi padi. Dan juga sejalan dengan pernyataan Jumiati (2016) bahwa peningkatan luas panen dapat meningkatkan produksi padi Kecamatan Sinjai Selatan.

Semakin banyak bidang sawah yang digarap oleh buruh tani dalam satu waktu maka akan mendatangkan hasil panen yang besar bagi mereka dikarenakan luas daerah panen yang banyak. Sehingga akan mendatangkan keuntungan yang berlimpah bagi buruh tani. Dan 
sebaliknya apabila sedikit bidang yang digarap maka kemungkinan besar hasil perolehan panen pun juga sedikit karena luas panen yang kecil. Sehingga pendapatan yang diperoleh pun juga sedikit.

Beberapa faktor diatas merupakan salah satu penyebab kecilnya pendapatan keluarga buruh tani di Desa Bakung Pringgodani. Status sebagai buruh tani yang tidak memiliki lahan harus melakukan sistem bagi hasil dengan pemilik lahan menjadikan faktor paling utama kecilnya pendapatan dari hasil aktivitas pertanian yang tergolong rendah apabila dihadapkan untuk memenuhi begitu banyak kebutuhan rumah tangga sehingga memaksa buruh tani di Desa Bakung Pringgodani untuk mendatangkan pendapatan selain kerja sebagai buruh tani.

Dimana buruh tani memiliki pekerjaan sampingan sebagai pekerja serabutan, pegawai tidak tetap, berdagang, dan kuli bangunan untuk memperoleh penghasilan tambahan guna untuk mencukupi kebutuhan yang belum bisa tercover sepenuhnya oleh pendapatan yang diperoleh dari hasil aktivitas pertanian. Oleh karena itu, buruh tani di Desa Bakung Pringgodani memiliki pekerjaan sampingan yang membawa dampak positif dalam kondisi keuangan keluarga. Namun, pekerjaan sampingan yang dilakukan oleh buruh tani di Desa Bakung Pringgodani pun juga tidak menghasilkan pendapatan yang begitu besar. Hal ini disebabkan oleh beberapa faktor yaitu sebagai berikut.

Tingkat Pendidikan, sebagian besar buruh tani di Desa Bakung Pringgodani memiliki tingkat pendidikan yang rendah. dengan pendidikan terakhir Sekolah Dasar (SD) hingga Sekolah Menengah Pertama(SMP). Tingkat pendidikan yang tergolong rendah tersebut membuat buruh tani sulit hingga tidak mampu mendapatkan pekerjaan sampingan yang lebih memadai. Dengan pekerjaan sampingan yang tidak cukup memadai maka pendapatan yang diperoleh pun tergolong sedikit pula. Hal ini sejalan dengan pernyataan Dedi Julianto dan Puti Annisa Utari (2019) bahwa pekerja dengan pendidikan yang lebih rendah mempunyai pendapatan yang rendah dibandingkan dengan pekerjaan yang memiliki tingkat pendidikan yang lebih tinggi.

Keterampilan dalam bekerja merupakan kemampuan seseorang dalam melaksanakan suatu pekerjaan yang dapat dikuasai dari pembelajaran atau bantuan orang lain. Buruh tani di Desa Bakung Pringgodani karena bertani merupakan profesi mereka maka keterampilan yang dimiliki hanya dalam lingkup aktivitas pertanian sehingga dalam bekerja sampingan tidak bisa memperoleh pendapatan yang maksimal dikarenakan keterampilan buruh tani dalam pekerjaan lain dinilai biasa saja sehingga mempengaruhi produktivitas dalam bekerja yang membuat pendapatan yang diperoleh tidak bisa maksimal. Hal ini sejalan dengan penelitian Wiwin Wiranti (2016) yang menyatakan bahwa secara individu keterampilan memiliki pengaruh terhadap produktivitas kerja. Dimana kemampuan keterampilan yang baik dan stabil dapat mendorong produktivitas kerja sehingga secara otomatis bisa memaksimalkan pendapatan.

Usia menjadi salah satu faktor yang dapat mempengaruhi tingkat pendapatan. Kekuatan fisik dalam dalam melakukan aktivitas akan sangat berkaitan erat dengan usia, karena jika usia telah melewati masa produktif maka akan semakin menurun kekuatan fisik yang ada sehingga tingkat produktivitas dalam bekerja juga berkurang yang bisa berakibat pada pendapatan yang diperoleh. Hampir seluruh buruh tani di Desa Bakung Pringgodani sudah lanjut usia dan tidak berada dalam usia produktif, sehingga dalam bekerja kurang maksimal sehingga pendapatan yang diperoleh dari pekerjaan sampingan tergolong masih rendah. Hal ini sesuai dengan 
pernyataan Arya Dwianda dan Nyoman Djinar Setiawina (2013) bahwa seseorang yang berada dalam usia produktif akan mampu memperoleh pendapatan yang lebih tinggi dibandingkan dengan seseorang yang berada di usia non produktif.

Beberapa faktor tersebut yang menjadi penyebab pendapatan buruh tani dari pekerjaan sampingan mereka yang tergolong kecil. Pekerjaan sampingan ini dilakukan oleh buruh tani adalah untuk menambah pendapatan dari aktivitas pertanian yang rendah dalam memenuhi kebutuhan keluarga seperti biaya pangan, sandang, biaya pendidikan anak, biaya listrik, biaya untuk berobat, biaya untuk membayar arisan, dan biaya untuk membayar hutang. Dan pekerjaan sampingan yang dimiliki oleh buruh tani di Desa Bakung Pringgodani memiliki kontribusi yang cukup berarti dalam memenuhi kebutuhan dan meningkatkan taraf hidup bagi keluarga agar lebih sejahtera.

Keluarga buruh tani di Desa Bakung Pringgodani memiliki dua sumber pendapatan, dimana terdiri dari pendapatan dari aktivitas bertani dan pendapatan dari pekerjaan sampingan. Seluruh pendapatan yang diperoleh baik dari aktivitas pertanian maupun dari pekerjaan sampingan akan menjadi pendapatan keluarga yang akan dialokasikan untuk biaya kebutuhan hidup. Apabila keluarga buruh tani di Desa Bakung Pringgodani hanya mengandalkan pendapatan yang diperoleh dari hasil pertanian maka niscaya seluruh kebutuhan hidupnya tidak akan mampu terpenuhi karena pendapatan dari hasil panen yang tergolong kecil. Dengan adanya pendapatan yang diperoleh keluarga buruh tani dari pekerjaan sampingan sebagai pekerja serabutan, pegawai tidak tetap, atau sebagai pelaku usaha kecil akan menambah nilai nominal yang didapatkan sehingga mampu menutupi kekurangan dalam pemenuhan kebutuhan yang masih belum terpenuhi dari pendapatan yang diterima dari hasil pendapatan sebagai buruh tani.

\subsection{Pola Pengelolaan Pendapatan Keluarga Buruh Tani}

Keluarga buruh tani di Desa Bakung Pringgodani seringkali menghadapi guncangan ekonomi dalam rumah tangga mereka apabila terjadi puso yang menyebabkan mereka tidak mendapatkan hasil apapun dari pertanian. Sedangkan keluarga buruh tani di Desa Bakung Pringgodani memiliki kebutuhan yang tidak sedikit untuk menunjang kehidupan mereka. Kebutuhan keluarga dari buruh tani di Desa Bakung Pringgodani yaitu meliputi 1) kebutuhan primer diantaranya kebutuhan pokok rumah tangga, kebutuhan akan listrik, keperluan untuk membayar arisan dan kredit, 2) kebutuhan sekunder diantaranya kebutuhan untuk biaya pendidikan anak, biaya pengobatan, alat transportasi, perabotan rumah tangga, biaya pulsa dan uang jajan, dan 3) kebutuhan tersier ini kebutuhan akan barang mewah diantaranya perhiasan emas. Dengan begitu buruh tani di Desa Bakung Pringgodani memiliki pekerjaan lain selain menjadi buruh tani sebagai penghasilan tambahan dalam rangka untuk mencukupi kebutuhan hidup rumah tangga mereka yang tidak sedikit.

Dengan memiliki dua sumber penghasilan tak pelak membuat kehidupan buruh tani di Desa Bakung Pringgodani membaik. Pendapatan dari pertanian yang kadang kala tidak stabil dan pendapatan dari pekerjaan sampingan yang tidak begitu besar terkadang membawa mereka dalam kesulitan. Dengan melihat pendapatan yang diterima dan pengeluaran akan kebutuhan yang diperlukan oleh keluarga buruh tani di Desa Bakung Pringgodani ditemukan bawasanya terdapat 3 macam pola yang diterapkan keluarga buruh tani di Desa Bakung Pringgodani dalam mengelola pendapatan dalam rangka untuk memenuhi berbagai macam 
kebutuhan rumah tangga. Pola yang diterapkan berdasarkan pada aliran pendapatan dan pengeluaran. Dimana pendapatan yang masuk akan dialokasikan untuk pengeluaran akan kebutuhan apa saja.

Berikut merupakan pola pengelolaan pendapatan keluarga buruh tani di Desa Bakung Pringgodani untuk memenuhi kebutuhan hidup setiap harinya:

Menggabungkan seluruh pendapatan keluarga untuk memenuhi seluruh kebutuhan (Pola 1). Keluarga buruh tani yang dalam pengelolaan pendapatannya dengan menggabungkan seluruh pendapatan baik pendapatan hasil panen dan pendapatan sampingan untuk membiayai segala macam kebutuhan hidup keluarga dikarenakan dengan menggabungkan pendapatan dapat untuk mempermudah dalam mengalokasikan pendapatan dan mempermudah dalam mengatur pengeluaran untuk pemenuhan seluruh kebutuhan hidup. Selain itu, apabila seluruh pendapatan yang diperoleh digabungkan dan dikelola oleh satu orang akan lebih efektif dalam pengalokasian dan mengontrol keuangan. Hal ini sejalan dengan pernyataan Wahyu Putri Lestari (2020) bahwa penggabungan pendapatan dilakukan untuk mempermudah alokasi pengeluaran dan pengontrolan karena dilakukan oleh satu orang. Dengan menggabungkan pendapatan yang diperoleh akan mempermudah pengalokasian uang yang keluar untuk memenuhi berbagai kebutuhan keluarga. Keluarga buruh tani di Desa Bakung Pringgodani menerapkan pola pengelolaan dengan cara menggabungkan seluruh pendapatan keluarga ini karena lebih mudah dalam mengatur pendapatan yang masuk dan pendapatan yang keluar untuk dialokasikan pada pemenuhan seluruh kebutuhan keluarga. Pendapatan dari aktivitas bertani dan pekerjaan sampingan yang telah digabung ini digunakan untuk membiayai seluruh kebutuhan baik kebutuhan yang bersifat primer, sekunder maupun tersier. Penggabungan pendapatan ini dilakukan untuk mempermudah alokasi pendapatan dan pengontrolan pengeluaran yang dilakukan oleh satu orang yaitu biasanya oleh ibu rumah tangga.

Mengkhususkan pendapatan sampingan untuk kebutuhan primer dan pendapatan bertani untuk kebutuhan sekunder dan tersier (Pola 2). Keluarga buruh tani yang melakukan pengelolaan pendapatan dengan pola 2 ini memiliki jumlah pendapatan sampingan yang lebih besar dan stabil dari pendapatan yang diperoleh dari hasil panen yang tidak dapat diprediksi tiap musim panennya. Sejalan dengan penelitian yang dilakukan oleh Wahyu Putri Lestari (2020) menyatakan bahwa pendapatan yang jumlahnya lebih besar dan tetap setiap bulannya lebih diprioritaskan untuk memenuhi kebutuhan keluarga. Keluarga buruh tani di Desa Bakung Pringgodani menerapkan pola pengelolaan dengan mengkhususkan pendapatan sampingan untuk kebutuhan yang bersifat primer dikarenakan pendapatan dari pekerjaan sampingan yang diperoleh keluarga buruh tani lebih stabil dan dengan jumlah yang lebih besar sehingga dialokasikan untuk kebutuhan primer yang sifatnya harus segera dipenuhi demi kelangsungan hidup. Sedangkan pendapatan yang diperoleh dari aktivitas bertani yang tidak bisa diprediksi jumlahnya dialokasikan untuk kebutuhan sekunder maupun tersier yang sifat pemenuhannya tidak wajib. Selain itu dengan mengkhususkan tiap-tiap pendapatan untuk masing-masing kebutuhan, kita akan lebih mengetahui dengan rinci aliran pendapatan dan pengeluaran keuangan keluarga.

Mengkhususkan pendapatan bertani untuk kebutuhan primer dan pendapatan sampingan untuk kebutuhan sekunder dan tersier (Pola 3). Keluarga buruh tani di Desa Bakung Pringgodani yang melakukan pengelolaan pendapatan seperti pola 3 ini disebabkan 
karena pendapatan yang diperoleh dari hasil bertani memiliki jumlah yang lebih besar dari pada pendapatan yang diperoleh dari pekerjaan sampingan. Sejalan dengan penelitian yang dilakukan oleh Wahyu Putri Lestari (2020) menyatakan bahwa pendapatan yang jumlahnya lebih besar dan tetap setiap bulannya lebih diprioritaskan untuk memenuhi kebutuhan keluarga. Keluarga buruh tani di Desa Bakung Pringgodani menerapkan pola pengelolaan dengan mengkhususkan pendapatan dari aktivitas bertani untuk kebutuhan yang bersifat primer dikarenakan pendapatan dari hasil tani yang diperoleh keluarga buruh tani memiliki jumlah yang lebih besar sehingga dialokasikan untuk kebutuhan primer yang sifatnya harus segera dipenuhi demi kelangsungan hidup. Sedangkan pendapatan yang diperoleh dari pekerjaan sampingan yang jumlahnya tidak terlalu besar dialokasikan untuk kebutuhan sekunder maupun tersier yang sifat pemenuhannya tidak wajib. Selain itu dengan mengkhususkan tiap-tiap pendapatan untuk masing-masing kebutuhan, kita akan lebih mengetahui dengan rinci aliran pendapatan dan pengeluaran keuangan keluarga.

Dengan ketiga pola tersebut buruh tani di Desa Bakung Pringgodani mengelola pendapatannya guna untuk mengatur keuangan dalam keluarga mereka sehingga mereka dapat memenuhi kebutuhan hidup keluarga mereka. Pola tersebut terlihat dari aliran pendapatan dan pengeluaran dari masing-masing keluarga buruh tani di Desa Bakung Pringgodani. Dimana masing-masing keluarga memiliki polanya masing-masing, tergantung bagaimana cara mereka mengalokasikan pendapatannya sehingga dapat membentuk ketiga pola diatas.

\section{Simpulan}

Berdasarkan hasil penelitian dan pembahasan yang telah dipaparkan pada bab sebelumnya, maka kesimpulan yang dapat ditarik dari penelitian ini adalah sebagai berikut: 1) Pendapatan keluarga buruh tani di Desa Bakung Pringgodani ini terdiri dari pendapatan dari aktivitas bertani dan pendapatan dari pekerjaan sampingan. 2) Keluarga buruh tani di Desa Bakung Pringgodani Kecamatan Balongbendo Kabupaten Sidoarjo ditemukan 3 pola pengelolaan pendapatan keluarga, yaitu Pola 1: Menggabungkan seluruh pendapatan keluarga untuk memenuhi seluruh kebutuhan, Pola 2: Mengkhususkan pendapatan sampingan untuk kebutuhan primer dan pendapatan bertani untuk kebutuhan sekunder dan tersier, dan Pola 3: Mengkhususkan pendapatan bertani untuk kebutuhan primer dan pendapatan sampingan untuk kebutuhan sekunder dan tersier.

\section{Daftar Rujukan}

Abdurachman, A., A. Mulyani, dan N. L. Nurida. (2009). Kondisi dan Antisipasi Keterbatasan Lahan Pertanian di Pulau Jawa. Jurnal Pengembangan Inovasi Pertanian 2(4): 283-285.

Agustina Shinta. (2011). Ilmu Usahatani. Malang : Universitas Brawijaya Press.

Anniyah, Hidayatul., Agus Muliadi. (2018). Strategi Buruh Tani Dalam Memenuhi Kebutuhan Pendidikan Anak Di Desa Karang Baru Batu Rente Kecamatan Wanasaba kabupaten Lombok Timur. Jurnal Geodika Vol.1, No.1, Hal 1-6.

Badan Pusat Statistik. (2013). Jumlah Usahatani Indonesia 2003-2013. Survei Pertanian Indonesia HIm 43.

Badan Pusat Statistik. (2014). Indikator Kesejahteraan Rakyat. Badan Pusat Statistik. Jakarta

Badan Pusat Statistik. (2019). Perkembangan Upah Pekerja/Buruh. Berita Resmi Statistik No. 93/11/Th. XXII,

Bakri, Anggi Hadi Sovian. (2018). Strategi Buruh Tani Dalam Memenuhi Kebutuhan Pokok (Studi Pada Buruh Tani di Dusun Calok, Desa Arjasa, Kecamatan Arjasa, Kabupaten Jember). Universitas Jember: Fakultas Ilmu Sosial dan Politik 
DITJEN PMPTK. (2008). Pendekatan, Jenis, dan Metode Penelitian Pendidikan. (online) http://staff.uny.ac.id/sites/default/files/PENELITIAN\%20PENDIDIKAN.pdf).

Dwianda, Arya dan Nyoman Djinar Setiawina. (2013). Pengaruh Umur, Pendidikan, Pekerjaan Terhadap Pendapatan Rumah Tangga Miskin di Desa Bebandem. E-Jurnal EP Unud, 2 [4] : 173-180.

Erleni, Saputri. (2015). Peranan Usaha Perabot Kayu Dalam Meningkatkan Pendapatan Masyarakat Menurut Ekonomi Islam (Studi Kasus Desa Kualu Kecamatan Tambang Kabupaten Kampar). Skripsi. Riau: Universitas Negeri Islam Sultan Syarif Kasim Riau.

Ggarg, Taruna. (2011). Budgeting as a Means to Manage Household Finances. BVIMSR 3(2) : 1-17.

Gusmira, E., Susanti, T., \& Ma'rufi, A. (2018). Model Fuzzy Logic Berbasis Anfis Dalam Penentuan Pola Tanam Oryza Sativa. Al-Kauniyah, 11(2), 171-182.

Iskandar. (2009). Metodologi Penelitian Pendidikan dan Sosial (Kuantitatif Dan Kualitatif). Jakarta : GP. Press.

Julianto, Dedi dan Puti Annisa Utari. (2019). Analisa Pengaruh Tingkat Pendidikan Terhadap Pendapatan Individu Di Sumatera Barat. Ikraith Ekonomika Vol 2 No 2.

Lestari, Yeni., Sri Hartati, dan Heni Nopianti. (2016). Pemenuhan Kebutuhan Hidup Rumah Tangga Petani Miskin (Studi Kasus pada Petani Penggarap di Dusun II Talang Watas Desa Muara Langkap Kecamatan Bermani Ilir, Kabupaten Kepahiang). Jurnal Sosiologi Nusantara Vol.2, No.2.

Pratama, Putra. (2019). Analisis Pengelolaan Keuangan Keluarga Buruh Tani Dalam Rangka Mempersiapkan Pendidikan Anak. Universitas Negeri Malang : Fakultas Ekonomi dan Bisnis.

Rahardjo Mudjia. (2007). Sosiologi pedesaan "studi perubahan sosial. Malang : UIN Malang Press

Ridwan. (2015). The HandBook of Family Financial Planning Mengelola Keuangan Keluarga Secara Islami. FEBI UN-SU Press.

Rini, Mike. (2009). Perencanaan Keuangan Bagi Buruh Migran Perempuan. SMK Grafika Desa Putra.

Rostiana, Endang dan Horas Djulius. (2018). Perencanaan dan Pengelolaan Keungan Dalam MewujudkanKeluarga Sejahtera. Yogyakarta : Diandra Kreatif.

Santoso, Slamet. (2010). Teori-Teori Psikologi Sosial. Bandung: Refika Aditama.

Senduk, Safir. (2000). Seri Perencanaan Keuangan Keluarga Mengelola Keuangan Keluarga. Jakarta : PT Elex Media Komputindo.

Setiaji, Hidayat. (2019). RI Terancam Krisis Petani, Upah Kecil \& Miskin Terus. (Online) https://www.cnbcindonesia.com/newa/20191115141634-4-115591/pantesan-ri-terancam-krisispetani-upah-kecil-miskin-terus/1.

Sugiyono. (2019) Metode Penelitian Pendidikan Pendekatan Kuantitatif, Kualitatif dan R\&D. Bandung : Alfabeta.

Susilowati, Sri Hery, Supadi, dan Chaerul Saleh. (2002). Diversifikasi Sumber Pendapatan Rumah Tangga Di Pedesaan Jawa Barat. Journal of Agricultural Economy 20(1) :85-109.

Wahyuni, Dwi. (2016). Analisis Sistem Pengupah "Bawon” Pada Pertanian Padi (Studi Kasus Pada Petani di Desa Gambar Kecamatan Wonodadi Kabupaten Blitar). Jurnal Bisnis, Manajemen \& Perbankan Vol. 2 No. 2.

Wati, Herlina dan Charina Chazali. (2013). Sistem Pertanian Padi Indonesia dalam Perspektif Efisiensi Sosial. AKATIGA, Pusat Analisis Sosial.

Wiranti, Wiwin. (2016). Pengaruh Keterampilan Terhadap Produktivitas Kerja Karywan Pada Konveksi Istana Mode Madiun. Equilibrium, Volume 4, Nomor 1. 